International Journal of Software Engineering \& Applications (IJSEA), Vol.3, No.1, January 2012

\title{
Risk Management Measures in CMMI
}

\author{
Mahmoud Khraiwesh \\ Faculty of Science and Information Technology \\ Zarqa University \\ Zarqa - Jordan \\ mahmoud@pu.edu $\cdot$ jo
}

\begin{abstract}
Risk management is a continuous process that could endanger the objectives of a project or application. Risks are handled to reduce and avoid threats effects on the objectives of the project. The sources of risk are both internal and external to the project. This research will identify general measures for the specific goal and its specific practices of Risk Management Process Area (PA) in Capability Maturity Model Integration (CMMI). CMMI is developed by Software Engineering Institute (SEI) in Carnegie Mellon University in USA. CMMI is a framework for improvement and assessment of computer information systems. The method we used to define the measures is to apply the Goal Questions Metrics (GQM) paradigm to the specific goals and its specific practices of Risk Management Process Area in CMMI.
\end{abstract}

\section{KEYWORDS}

Risk Management, Measures, CMMI, GQM.

\section{INTRODUCTION}

Risk management is a continuous process that addresses issues that could endanger the objectives of a computer information system [10]. By identifying and controlling the risks, one may make better and daring decisions when talking on complex challenging projects or when exploring new unknown grounds [12]. Many studies have proven that proper management of software risks effects the success of software development projects [21][35]. Risk management has been known in various domains such as business, manufacturing, health care, computer information system, and others [22].

Achieving effective software risk management requires project managers to understand the nature of software risks [18]. As organizations invest substantial resources and efforts on software development, controlling the risks associated with software projects becomes crucial [25]. Risk management is concerned with identifying risks and plans to minimise their effect on a project. Risks may threaten the software that is being developed or the organization. Risk management is one of the important jobs of project managers [33].

The purpose of the risk management is to identify potential problems before they occur so that risk handling activities can be planned and invoked as needed across the life of the product or project to mitigate adverse impacts on achieving objectives. Risk management is a continuous process that is an important part of project management [32]. Results show that there is increasing research in risk management and the need for more studies [34]. Risk management in the early stages of the system life cycle allows the identification and analysis of risks, and establishes strategies to mitigate them, in order to control risks from beginning to end [4]. Risk management is an important and necessary process in software engineering. Its implementation is needed throughout the project life cycle. Its aim is to prevent risks before they occur and to establish control mechanisms [2]

DOI : $10.5121 /$ ijsea.2012.3111 
International Journal of Software Engineering \& Applications (IJSEA), Vol.3, No.1, January 2012

Measurement is the heart of risk management, without measurement it would be impossible to identify, assess and mitigate risks. Measurement is a valuable software management support tool [24]. Measurement is the key to effective process management. Measurement is a mechanism for characterizing, evaluating, and predicting software processes and products [5]. The way to improve a process is to measure specific attributes of the process, develop a set of metrics based on these attributes, and use the metrics to provide indicators that lead to strategy for improvement. Software measurement plays important role in understanding and controlling software processes and products [23].

Measurement is the process by which numbers or symbols are assigned to attributes of entities in the real world in such a way as to characterize the attributes by clearly defined rules (and scales) [15]. Measurement is important for three activities: understanding, control and improvement [14]. Reasons for measuring are: to assess achievement of goals, to determine progress with respect to plans, to gain understanding of processes, products, and environments, to make baselines for comparisons with future assessments and track improvement [29]. The measurement objective is to monitor software process performance [28].

Software measurement is in a phase in which terminology, principles and methods are being defined. We should not expect to define quantitative laws that are generally valid and applicable, and have the same accuracy as the laws of physics, for instance. The identification of universally valid and applicable measures may be an ideal, long term research goal, which cannot be achieved in the near future [9]. Software engineering is not grounded in the quantitative laws of physics. Direct measure such as mass, velocity, or temperature, are uncommon in the software engineering. Because software metrics are often indirect and open to debate [31]. There is no agreed-upon metrics validation framework [19]. The goal of software metrics is to improve the software process [13].

In the mid-1980s, the SEI initiated a study for assessing the capabilities of software contractors. The outcome of this study was the Software Capability Maturity Model for Software (SW-CMM) [30]. The Software CMM was followed by other models, including the People Capability Maturity Model (P- CMM) [11]. Organizations from industry, government, and the Software Engineering Institute (SEI) joined to develop the CMMI framework, a set of integrated CMMI models. Two kinds of materials are contained in the CMMI model [1]:

1. Materials to help you evaluate the contents of processes information that is essential to technical and managerial activities.

2. Materials to help you improve process performance information that is used to increase the capability of organization's activities.

Through the process of adopting CMMI, we expect to attain the following objectives: 1) improve project management capability; 2) enhance product quality; 3) increase productivity and cost down; 4) improve the capability of predicting the project budget and schedule; 5) increase customer satisfaction [26]. The reward of adoption of CMMI is the software process improvement and the product quality enhancement. It also defines a common language and a uniform standard for staff members in daily tasks, and provides quantitative indicators for work performance and consolidates management [26].

CMMI model is quite comprehensive. It covers several bodies of knowledge and defined many process areas, specific and generic goals, specific and generic practices, and a lot of typical work products. CMMI should be used to improve processes, increase productivity, and raise competitiveness in the organization [36]. 
International Journal of Software Engineering \& Applications (IJSEA), Vol.3, No.1, January 2012

In CMMI-SW in each process area, there are one or more specific goals with specific practices and generic goals with generic practices. A specific goal applies to a process area and addresses the characteristics that describe what must be done to satisfy the process area. A specific practice is an activity that is considered important in achieving the associated specific goal. CMMI recognizes that a specific practice is the goal rather than the way that goal is reached [33].

The Goal/Question/Metric (GQM) paradigm to process and metrics was developed by Basili and Weiss [7] as a technique for identifying meaningful metrics for any part of the software process. GQM has proven to be effective approach to selecting and implementing metrics.

This paper defines a general measure for the three specific goals and its seven specific practices of Risk Management which is one of the PA in level 3 in CMMI-SW (Staged Representation) model. Measures will be compatible with the specific practices associated with each specific goal of Risk Management PA. The measures will be defined by applying Goal Question Metrics (GQM) paradigm to the specific goal and its specific practices of Risk Management PA. The defined measures will help us in controlling and evaluating the software processes and products.

The remainder of the paper is organized as follows: section 2 describes related work in software measurement for the CMMI, section 3 presents an overview of the CMMI, section 4 presents an overview of the GQM, section 5 describes the applying of the GQM to the CMMI, section 6 describes the validity and reliability of the defined measures, and section 7 presents conclusions.

\section{RELATED WORK}

Many software measures activities have been proposed in the literature, some of them are [8] [17] [20] [27] [30]. The most related to our work are [8] [30] and [27]. Baumert and McWhinney [8] define a set of indicators that are compatible with the measurement practices (one of the common features) described in the Capability Maturity Model for Software CMM. These indicators cover thirteen categories. Categories are not occur at all maturity levels and don't focus on a specific process. Their work was related to CMM not CMMI. Paulk, Weber, Garcia, Crissis and Bush [30] define a set of examples of measurements in measurement practices (one of the common features) of the Capability Maturity Model for Software (CMM) in KPAs. A few examples related to requirements management KPA were defined. They don't focus on a specific process, their work was based on CMM not CMMI. Loconsole [27] defined software measurements for implementation of Requirements Management KPA of the CMM. Loconsole work related to CMM not CMMI.

This paper presents a set of measures that are focused on a specific PA, Risk Management PA of the CMMI-SW. Measures are for the three specific goals and its seven specific practices of Risk Management PA.

\section{OVERVIEW OF THE CMMI-SW}

The CMMI (Staged Representation) is composed of five maturity levels: Initial, Managed, Defined, Quantitatively Managed and Optimizing. Figure1 shows the five maturity levels. Each maturity level is composed of several key process areas with the exception of Level1 [32]. In CMMI within each process area, there is one or more specific goals with specific practices and generic goals with generic practices. Generic goals are related to the institutionalization of good practice, they called 'generic' because the same goal statement appears in multiple process areas as shown in figure 2. A specific goal applies to a process area and addresses the unique characteristics that describe what must be implemented to satisfy the process area. A specific practice is an activity that is considered important in achieving the associated specific goal [32]. 
International Journal of Software Engineering \& Applications (IJSEA), Vol.3, No.1, January 2012

The purpose of Risk Management (RSKM) is to identify potential problems before they occur so that risk

handling activities can be planned and invoked as needed across the life of the product or project to mitigate adverse impacts on achieving objectives [32]. The specific goals associated with Risk Management process area and the specific practices associated with each specific goal:

1. Prepare for Risk Management

1.1 Determine Risk Sources and Categories

1.2 Define Risk Parameters

1.3 Establish a Risk Management Strategy

2. Identify and Analyze Risks

2.1 Identify Risks

2.2 Evaluate, Categorize, and Prioritize Risks

3. Mitigate Risks

3.1 Develop Risk Mitigation Plans

3.2 Implement Risk Mitigation Plans

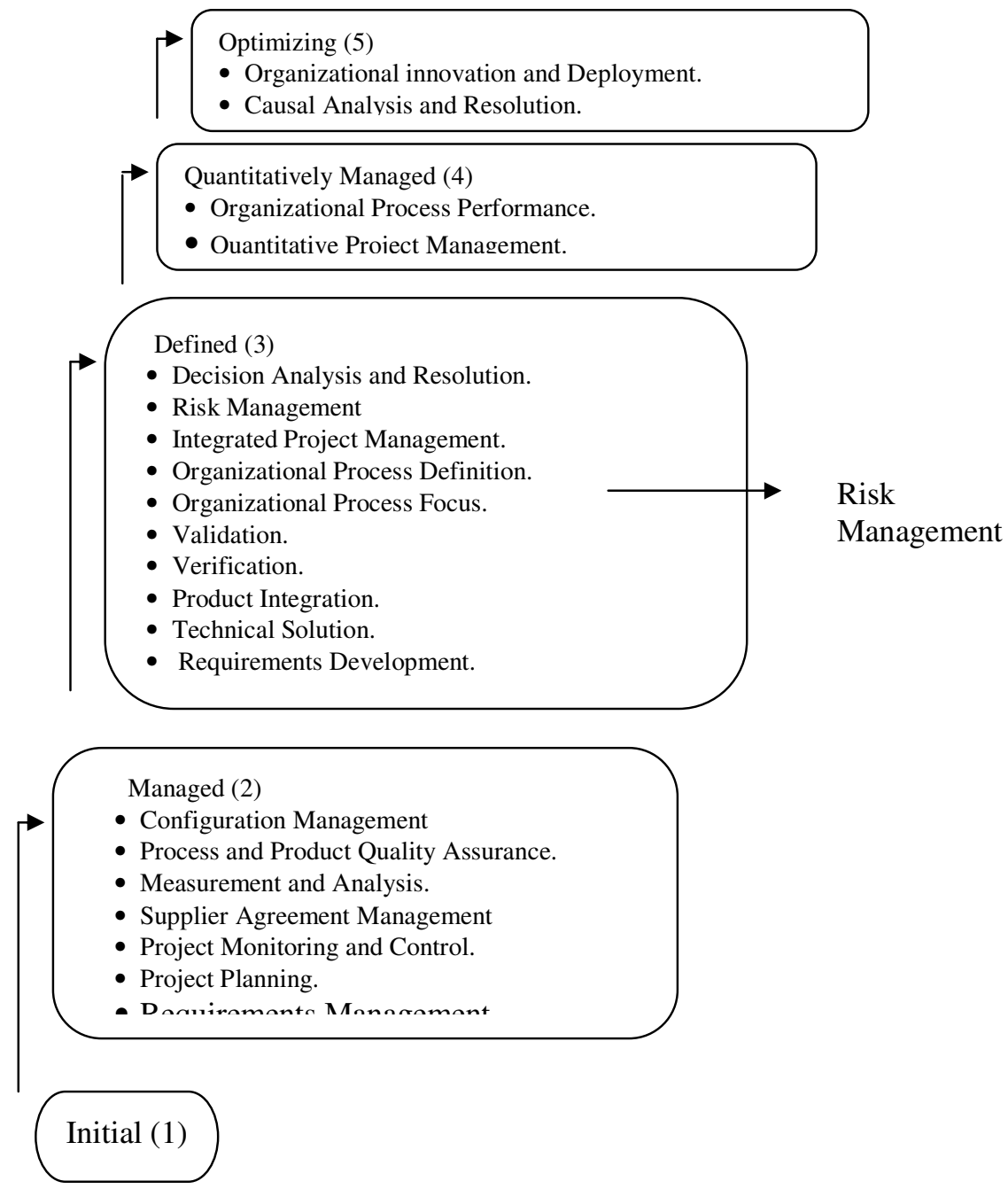

Figure 1. five levels with PA's in CMMI. 
International Journal of Software Engineering \& Applications (IJSEA), Vol.3, No.1, January 2012

\section{OVERVIEW OF THE GQM}

The Goal/Question/Metric (GQM) paradigm is used for helping an organization to focus the measurement program on their goals. GQM states that an organization should have specific goals in before data are collected [5]. The more mature your process, the more that is measurable. GQM does not specify concrete goals. It is a structure for defining goals and refining them into a set of quantifiable questions, these questions imply a set of metrics and data to be collected in order to achieve these goals.

The GQM paradigm consists of three steps:

1. Specify a set of goals based on the needs of the organization's projects. Determine what should be improved or learned. The process of goal definition is supported by templates, by using these templates we can define the goals in terms of purpose, perspective, and environment. Measurement goals should be understandable and should be clearly structured. For this reason, templates are available to support the definition of measurement goals by specifying purpose (what object and why), viewpoint (what aspect and who), and context characteristics [6].

2. Generate a set of quantifiable questions. Goals are translated into operational statements with a measurement focus. Basili and Rombach [5] provide sets of guidelines to classify questions related to products or processes.

3. Define a set of metrics that provide the quantitative information to answer the quantifiable questions. The metrics suitable to provide information to answer the questions are identified and related to each question. Several metrics may be generated from a single goal. Several measurements may be needed to answer a question. A single measurement may apply to more than one question.

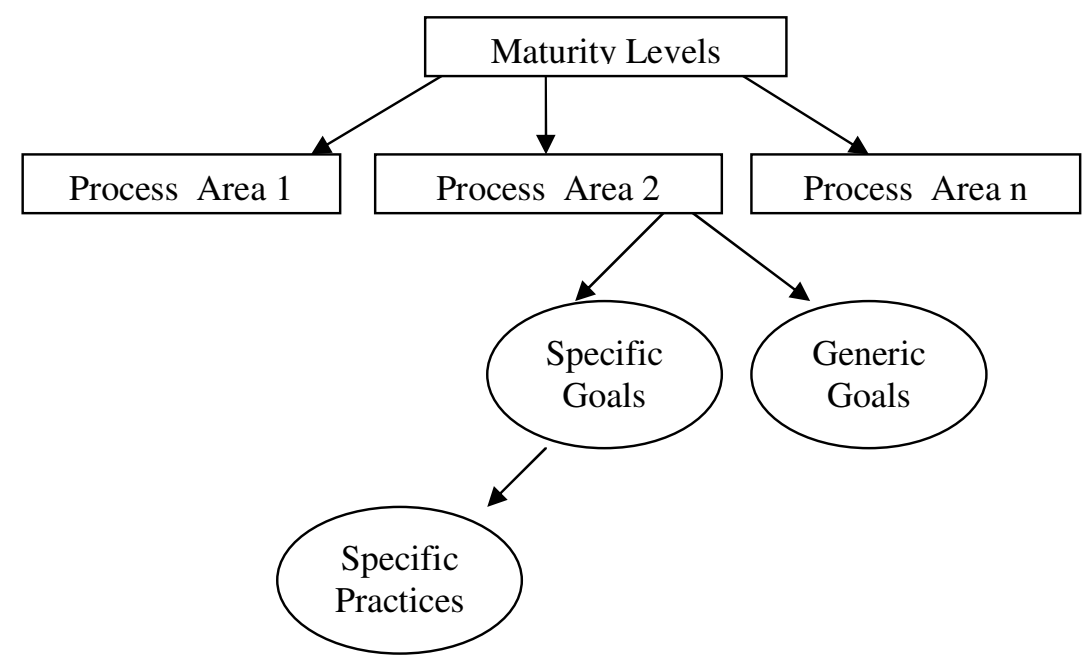

Figure 2. specific and generic goals

\section{APPLYING GQM TO THE CMMI-SW}

The CMMI-SW defines three specific goals for Risk Management PA. There are seven specific practices related to the specific goals. We will deal with the specific practices as goals. We will apply the GQM on the seven specific practices.

The seven specific practices associated with Risk Management process area are: 
International Journal of Software Engineering \& Applications (IJSEA), Vol.3, No.1, January 2012

1. Determine risk sources and categories

2. Define risk parameters: define parameters used to analyze and categorize risks to control the risk management effort.

3. Establish a risk management strategy: establish and maintain the strategy to be used for risk management.

4. Identify risks: identify and document risks.

5. Evaluate, categorize, and prioritize risks: evaluate and categorize each identified risk using defined risk categories and parameters, and determine its relative priority.

6. Develop risk mitigation plans: develop a risk mitigation plan in accordance with the risk management strategy.

7. Implement risk mitigation plans: monitor the status of each risk periodically and implement the risk mitigation plan as appropriate.

These seven specific practices can be used for the first step of the GQM. The second step of the GQM is to generate a set of quantifiable questions. The third step of the GQM is to define a set of metrics that provide the quantitative information to answer the questions. The sub practices and the typical work products in each specific practice are take in consideration when we identify the set of measures. A set of questions and measures is presented in the following tables, table 1 through table 7 , each table related to one specific practice. There are overlaps among the questions and the measures. The same measure can be used to answer different questions.

\subsection{Measures for specific practice 1 .}

Determine Risk Sources and Categories.

A set of questions and measures is presented in the following table related to specific practice 1.

Table 1. Set of questions and measures for specific practice 1.

\begin{tabular}{|c|c|c|}
\hline & Questions & Measures \\
\hline Q1 & $\begin{array}{l}\text { Do you identify risk resources that } \\
\text { affect the ability of the project to meet } \\
\text { its objectives? }\end{array}$ & $\begin{array}{l}\text { - Identifying risk resources that affect the } \\
\text { ability of the project to meet its objectives. } \\
\text { - \# Risk resources. } \\
\text { (\# means number of) }\end{array}$ \\
\hline $\mathrm{Q} 2$ & Do you identify internal risk resources? & $\begin{array}{l}\text { - Identifying internal risk resources. } \\
\text { - \# Internal risk resources. }\end{array}$ \\
\hline Q3 & $\begin{array}{l}\text { Do you identify external risk } \\
\text { resources? }\end{array}$ & $\begin{array}{l}\text { - Identifying external risk resources. } \\
\text { - \# External risk resources. }\end{array}$ \\
\hline Q4 & $\begin{array}{l}\text { Do you identify additional resources as } \\
\text { the project progresses? }\end{array}$ & $\begin{array}{l}\text { - Identifying additional resources as the } \\
\text { project progresses. } \\
\text { - \# Additional resources. }\end{array}$ \\
\hline Q5 & $\begin{array}{l}\text { Do you establish categories for risks? } \\
\text { (Risk categories are used for collecting } \\
\text { and organizing risks such as budget } \\
\text { risks, schedule risks, contract risks). }\end{array}$ & $\begin{array}{l}\text { - Establishing categories for risks. } \\
\text { - \# risks in each risk category. }\end{array}$ \\
\hline Q6 & $\begin{array}{l}\text { Do you identify appropriate } \\
\text { management attention to risks that have } \\
\text { serious consequences on meeting } \\
\text { project objectives? }\end{array}$ & $\begin{array}{l}\text { - Identifying risks that have serious } \\
\text { consequences on meeting project objective. } \\
\text { - \# risks that have serious consequences on } \\
\text { meeting project objectives. }\end{array}$ \\
\hline
\end{tabular}


International Journal of Software Engineering \& Applications (IJSEA), Vol.3, No.1, January 2012

\subsection{Measures for specific practice 2 .}

Define Risk Parameters: Define parameters used to analyze and categorize risks and to control the risk management effort.

A set of questions and measures is presented in the following table related to specific practice 2 .

Table 2. Set of questions and measures for specific practice 2.

\begin{tabular}{|c|c|c|}
\hline & Questions & Measures \\
\hline Q1 & $\begin{array}{l}\text { Do you define parameters for evaluation, } \\
\text { categorizing and prioritizing risks? } \\
\text { Parameters include risk likelihood, risk } \\
\text { consequences, and threshold to trigger } \\
\text { management activity. }\end{array}$ & $\begin{array}{l}\text { - Defining parameters for evaluation, } \\
\text { categorizing and prioritizing risks. } \\
\text { - \# parameters for evaluating, categorizing } \\
\text { and prioritizing risks. }\end{array}$ \\
\hline Q2 & $\begin{array}{l}\text { Do you define the probability of risk } \\
\text { occurrence for each risk? }\end{array}$ & $\begin{array}{l}\text { - Defining the probability of risk occurrence } \\
\text { for each risk. }\end{array}$ \\
\hline Q3 & $\begin{array}{l}\text { Do you define the impact and severity } \\
\text { of risk occurrence for each risk? }\end{array}$ & $\begin{array}{l}\text { - Defining the impact and severity level of } \\
\text { risk occurrence for each risk. }\end{array}$ \\
\hline Q4 & $\begin{array}{l}\text { Do you define the threshold to trigger } \\
\text { management activity for each risk } \\
\text { category? } \\
\text { (e.g., performance threshold, schedule } \\
\text { threshold, cost threshold). }\end{array}$ & $\begin{array}{l}\text { Defining the threshold to trigger } \\
\text { management activity for each risk } \\
\text { category. }\end{array}$ \\
\hline Q5 & $\begin{array}{l}\text { Do you define the severity level of each } \\
\text { risk?. }\end{array}$ & - Defining the severity level of each risk. \\
\hline
\end{tabular}

\subsection{Measures for specific practice 3 .}

Establish a Risk Management Strategy: Establish and maintain the strategy to be used for risk management.

A set of questions and measures is presented in the following table related to specific practice 3.

Table 3. Set of questions and measures for specific practice 3

\begin{tabular}{|l|l|l|}
\hline Q1 & Questions & $\begin{array}{l}\text { Do you establish and maintain strategy } \\
\text { for risk management? } \\
\text { (strategy items include: methods and } \\
\text { tools, sources of risks, mitigation } \\
\text { techniques ) }\end{array}$ \\
\hline
\end{tabular}


International Journal of Software Engineering \& Applications (IJSEA), Vol.3, No.1, January 2012

\begin{tabular}{|c|c|c|}
\hline Q2 & $\begin{array}{l}\text { Do you identify methods and tools to be } \\
\text { used for risk identification, risk analysis, } \\
\text { risk mitigation and risk monitoring? }\end{array}$ & $\begin{array}{l}\text { - Identifying methods and tools to be used. } \\
\text { - \# methods and tools to be used. }\end{array}$ \\
\hline Q3 & $\begin{array}{l}\text { Do you identify risk mitigation } \\
\text { techniques to be used, such as } \\
\text { prototyping, simulation, piloting? }\end{array}$ & $\begin{array}{l}\text { - Identifying risk mitigation techniques to } \\
\text { be used. } \\
\text { - \# mitigation techniques to be used. }\end{array}$ \\
\hline Q4 & $\begin{array}{l}\text { Do you review the strategy with relevant } \\
\text { stakeholders? }\end{array}$ & $\begin{array}{l}\text { - Reviewing the strategy with relevant } \\
\text { stakeholder. } \\
\text { - \# relevant stakeholders who share the } \\
\text { review. }\end{array}$ \\
\hline Q5 & $\begin{array}{l}\text { Do you develop the risk management } \\
\text { strategy early in the project? }\end{array}$ & $\begin{array}{l}\text { - Developing the risk management strategy } \\
\text { early in the project. }\end{array}$ \\
\hline
\end{tabular}

\subsection{Measures for specific practice 4.}

Identify Risks: Identify and document risks.

A set of questions and measures is presented in the following table related to specific practice 4.

Table 4. Set of questions and measures for specific practice 4.

\begin{tabular}{|c|c|c|}
\hline Q1 & $\begin{array}{l}\text { Do you document risks in a concise } \\
\text { statement that include context, } \\
\text { conditions, and consequences? }\end{array}$ & $\begin{array}{l}\text { - Documenting risks in a concise } \\
\text { statement. } \\
\text { - \# risks which are documented in a } \\
\text { concise statement. }\end{array}$ \\
\hline Q2 & $\begin{array}{l}\text { Do you review risks periodically to } \\
\text { reexamine possible sources of risks? }\end{array}$ & $\begin{array}{l}\text { - Reviewing risks periodically to } \\
\text { reexamine possible sources of risks. } \\
\text { - \# new sources of risks. }\end{array}$ \\
\hline Q3 & $\begin{array}{l}\text { Do you review risk management } \\
\text { efforts from similar product? }\end{array}$ & $\begin{array}{l}\text { - Reviewing risk management efforts } \\
\text { from similar product. }\end{array}$ \\
\hline Q4 & $\begin{array}{l}\text { Do you examine each element of the } \\
\text { project structure? }\end{array}$ & $\begin{array}{l}\text { - Examining each element of the project } \\
\text { structure. } \\
\text { - \# elements examined in the project. }\end{array}$ \\
\hline Q5 & $\begin{array}{l}\text { Do you identify risks that can be } \\
\text { associated with the organization's } \\
\text { operations such as strikes, and } \\
\text { diminishing sources of supply } \\
\text { competition? }\end{array}$ & $\begin{array}{l}\text { - Identify risks that can be associated with } \\
\text { the organization's operations. } \\
\text { - \# risks that associated with the } \\
\text { organization's operations }\end{array}$ \\
\hline
\end{tabular}


International Journal of Software Engineering \& Applications (IJSEA), Vol.3, No.1, January 2012

\begin{tabular}{|c|c|c|}
\hline Q6 & $\begin{array}{l}\text { Do you review potential } \\
\text { environmental risks, which include } \\
\text { weather or natural disaster, and } \\
\text { political changes? }\end{array}$ & $\begin{array}{l}\text { - Reviewing potential environmental } \\
\text { risks. } \\
\text { - \# potential environmental risks. }\end{array}$ \\
\hline Q7 & $\begin{array}{l}\text { Do you identify relevant stakeholders } \\
\text { associated with each risk? }\end{array}$ & $\begin{array}{l}\text { - Identifying relevant stakeholders } \\
\text { associated with each risk. } \\
\text { - \# stakeholders associated with each }\end{array}$ \\
\hline
\end{tabular}

\subsection{Measures for specific practice 5 .}

Evaluate, Categorize, and Prioritize Risks: Evaluate and categorize each identified risk using defined risk categories and parameters, and determine its relative priority.

A set of questions and measures is presented in the following table related to specific practice 5.

Table 5. Set of questions and measures for specific practice 5.

\begin{tabular}{|c|c|c|}
\hline & Questions & Measures \\
\hline Q1 & $\begin{array}{l}\text { Do you assign a value to each risk } \\
\text { according to defined risk parameters } \\
\text { include likelihood, consequence and } \\
\text { threshold? }\end{array}$ & $\begin{array}{l}\text { - Assigning a value to each risk according to } \\
\text { defined risk parameters. }\end{array}$ \\
\hline $\mathrm{Q} 2$ & $\begin{array}{l}\text { Do you combine the risk parameter } \\
\text { values to produce additional value } \\
\text { which can be used to prioritize risks? }\end{array}$ & $\begin{array}{l}\text { - Combining the risk parameter values to } \\
\text { produce additional value. } \\
\text { - \# levels to prioritize risks. }\end{array}$ \\
\hline Q3 & $\begin{array}{l}\text { Do you identify a scale to evaluate } \\
\text { likelihood of risks? } \\
\text { (e.g., remote, unlikely, likely, or } \\
\text { nearly) } \\
\text { (probability values are frequently used } \\
\text { to quantify likelihood) }\end{array}$ & $\begin{array}{l}\text { - Identifying a scale to evaluate likelihood } \\
\text { of risks. } \\
\text { - \# scale values which evaluate likelihood of } \\
\text { risks. }\end{array}$ \\
\hline $\mathrm{Q} 4$ & $\begin{array}{l}\text { Do you identify a scale to evaluate } \\
\text { consequences of risks ? } \\
\text { (e.g., low, medium, high, marginal, or } \\
\text { critical ) } \\
\text { (consequences are generally related to } \\
\text { cost, schedule, environmental impact, } \\
\text { or human impact ) }\end{array}$ & $\begin{array}{l}\text { - Identifying a scale to evaluate } \\
\text { consequences of risks. } \\
\text { - \# scale values which evaluate } \\
\text { consequences of risks. }\end{array}$ \\
\hline Q5 & $\begin{array}{l}\text { Do you prioritize risks based on the } \\
\text { assigned risk parameters? } \\
\text { ( prioritization determines the most } \\
\text { effective areas in the project to which } \\
\text { mitigation can be applied) }\end{array}$ & $\begin{array}{l}\text { - Prioritizing risks based on the assigned } \\
\text { risk parameters. } \\
\text { - \# levels to prioritize risks based on the } \\
\text { assigned risk parameters. }\end{array}$ \\
\hline
\end{tabular}

\subsection{Measures for specific practice 6 .}

Develop Risk Mitigation Plans: Develop a risk mitigation plan in accordance with the risk management strategy. 
International Journal of Software Engineering \& Applications (IJSEA), Vol.3, No.1, January 2012

A set of questions and measures is presented in the following table related to specific practice 6 .

Table 6. Set of questions and measures for specific practice 6 .

\begin{tabular}{|c|c|c|}
\hline & Questions & Measures \\
\hline Q1 & $\begin{array}{l}\text { Do you develop a risk mitigation } \\
\text { plan? } \\
\text { (risk mitigation plan includes } \\
\text { recommended actions and alternative } \\
\text { actions for each critical risk) } \\
\text { (risk mitigation plan also includes } \\
\text { techniques and methods used to avoid, } \\
\text { reduce, and control the probability of } \\
\text { risk occurrence) }\end{array}$ & - Developing a risk mitigation plan. \\
\hline Q2 & $\begin{array}{l}\text { Do you develop a contingency plan, } \\
\text { for risks which have high or } \\
\text { unacceptable consequences? }\end{array}$ & $\begin{array}{l}\text { - Developing a contingency plan, for risks } \\
\text { which have high } \\
\text { or unacceptable consequences. } \\
\text { - \# accepted risks. } \\
\text { - \# Unacceptable risks. }\end{array}$ \\
\hline Q3 & $\begin{array}{l}\text { Do you determine the acceptable } \\
\text { risks? } \\
\text { (acceptable risk is the risk which have } \\
\text { law level of impact and have law } \\
\text { mitigation) }\end{array}$ & $\begin{array}{l}\text { - Determining the acceptable risks. } \\
\text { - \# acceptable risks. }\end{array}$ \\
\hline Q4 & $\begin{array}{l}\text { Do you specify a person or a group to } \\
\text { track and address each risk? }\end{array}$ & $\begin{array}{l}\text { - Specifying a person or a group to track } \\
\text { and address each risk. } \\
\text { - \# persons to track and address each risk. }\end{array}$ \\
\hline Q5 & $\begin{array}{l}\text { Do you determine the level and } \\
\text { threshold that define where a risk } \\
\text { becomes unacceptable, so trigger the } \\
\text { execution of mitigation or } \\
\text { contingency plan? }\end{array}$ & $\begin{array}{l}\text { - Determining the level and threshold that } \\
\text { define where a risk becomes } \\
\text { unacceptable. }\end{array}$ \\
\hline
\end{tabular}

\subsection{Measures for specific practice 7.}

Implement Risk Mitigation Plans: Monitor the status of each risk periodically and implement the risk mitigation plan as appropriate.

A set of questions and measures is presented in the following table related to specific practice 7. 
International Journal of Software Engineering \& Applications (IJSEA), Vol.3, No.1, January 2012

Table 7. Set of questions and measures for specific practice 7.

\begin{tabular}{|c|c|c|}
\hline & Questions & Measures \\
\hline Q1 & $\begin{array}{l}\text { Do you monitor regularly the status of } \\
\text { each risk? } \\
\text { (regularly: defined intervals at which } \\
\text { risk status should be revisited.) } \\
\text { (monitor: compare the threshold } \\
\text { associated with each risk to the risk } \\
\text { status to determine the need of } \\
\text { implementing a risk mitigation plan or } \\
\text { contingency plan) }\end{array}$ & $\begin{array}{l}\text { - Monitoring regularly the status of each } \\
\text { risk. } \\
\text { - \# risks that are being monitored. }\end{array}$ \\
\hline Q2 & $\begin{array}{l}\text { Do you monitor regularly the results of } \\
\text { risk handing actions? }\end{array}$ & $\begin{array}{l}\text { - Monitoring regularly the results of risk } \\
\text { handing actions. } \\
\text { - \# risks that monitored regularly. }\end{array}$ \\
\hline Q3 & $\begin{array}{l}\text { Do you update the status of each risk } \\
\text { according to the regularly monitoring } \\
\text { of risk status? }\end{array}$ & $\begin{array}{l}\text { - Updating the status of each risk according } \\
\text { to the regularly monitoring of risk status. } \\
\text { - \# risks that their status have been updated. }\end{array}$ \\
\hline Q4 & $\begin{array}{l}\text { Do you update the risk handling } \\
\text { options according to the regularly } \\
\text { monitoring of risk handling actions? }\end{array}$ & $\begin{array}{l}\text { - Update the risk handling options } \\
\text { according to the regularly monitoring of } \\
\text { risk handling actions. }\end{array}$ \\
\hline Q5 & $\begin{array}{l}\text { Do you update risk likelihood, } \\
\text { consequences, and threshold according } \\
\text { to the regularly assessment? }\end{array}$ & $\begin{array}{l}\text { - Updating risk likelihood, consequences, } \\
\text { and threshold. } \\
\text { - \# updated risks. }\end{array}$ \\
\hline
\end{tabular}

\section{Validity and Reliability of The Defined Measures}

We have made a questionnaire to prove the reliability and validity of the defined sets of measures and confirm that these measures are actually measure the seven specific practices. The collected data will be analyzed by using cronbach alpha reliability in SPSS. The questionnaire was reviewed by academics in software engineering and practitioners in software development in Zarqa University. The questionnaire was filled by system analysts, software engineers, and students in software engineering department. The questionnaire consists of seven parts, each part is related to one specific practice of the Risk Management process, each part consists of a group of measures related to the specific practice, beside each measure there is five options: strongly agree, agree, neither agree nor disagree, disagree, strongly disagree. The questioner will read the statement and write his opinion of the statement relation with the specific practice by choosing one of the five options, a sample shown in Appendix A.

Cronbach alpha is designed to measure internal consistency, that is, do all items measure the same thing? ( measure a single unidirectional structure). Cronbach alpha values varies between 0 and 1 , the closer the alpha is to 1 , the greater the internal consistency of items being assessed [16]. If alpha is less than 0.5 then internal consistency is unacceptable [16]. After applying the collected data on Cronbach Alpha in SPSS we got alpha results between over 0.5 and less than 1. 
International Journal of Software Engineering \& Applications (IJSEA), Vol.3, No.1, January 2012

\section{Conclusions}

This paper identified a set of general measures for Risk Management Process Area (PA) in Capability Maturity Model Integration (CMMI-SW) Staged Representation. The way we used to define the measures is to apply the Goal Question Metrics (GQM) paradigm to the three specific goals and its seven specific practices of Risk Management PA. This work focuses on measurement of a specific process area rather than many process areas.

The set of measures identified in this paper provide the organization with better insight into the Risk Management activity, improving the software process towards the goal of having a managed process. The set of measures we defined can be used to control and evaluate software processes and products. Use of the measures varies with the maturity of the organization's process.

\section{REFERENCES}

[1] Ahern, D. M., Clouse, A. and Turner, R., CMMI Distilled: A Practical introduction to Integrated Process Improvement. Second edition, Addison - Wesley, 2003.

[2] Alea, M., "Information Technology Outsourcing (ITO) Go-vernance: An Examination of the Outsourcing Management Maturity Model," in Proceedings of the Proceedings of the 37th Annual Hawaii International Conference on System Sciences (HICSS'04) - Track 8 - Volume 8: IEEE Computer Society, 2004.

[3] Baker, W., Rees, L., and Tiippett, P., Necessary Measures metrice-Driven Information security Risk Assessment and decision making, in communication of the ACM, October 2007, vol.50, No 10

[4] Baldwin, A., Beres, Y. \& Shiu, S., "Using assurance models to aid the risk and governance life cycle" Springer Nether lands, vol. 25, pp. 128-140, Enero 2007.

[5] Basili, V. R. and Rombach, H. D., "The TAME Project: Towards Improvement-Oriented Software Environments", in IEEE Transactions on Software Engineering, vol. 14, no. 6, pp.758-773, 1988.

[6] Basili, V. R., Caldiera, C., Rombach, H. D., Goal Question Metric Paradigm, Encyclopedia of Software Engineering (Marciniak, J.J., editor), volume 1, John Wiley \& Sons, pp. 528-532, 1994.

[7] Basili, V. R., and Weiss, D. M., "A Methodology for collecting Valid Software Engineering Data", in IEEE Transactions on Software Engineering, volume. SE-10, pp.728-738, 1984.

[8] Baumert, J. H. and McWhinney, M. S., Software Measures and the Capability Maturity Model, Software Engineering Institute Technical Report, CMU/SEI-92-TR-25, ESC-TR-92-0, 1992.

[9] Briand, L.C., Morasca, S., and Basili, V. R., "An Operational Process for Goal Driven Definition of Measures", in IEEE Transactions on Software Engineering, vol. 28, no. 12, 2002.

[10] Chrissis, M. B., Konrad, M. and Shrum, S., CMMI, USA, Addison Wesley, 2005.

[11] Curtis, B., Hefley, W. E., Miller, S. The People Capability Model : Guidelines for Improving the Workforce. Boston : Addison Wesley, 2001.

[12] Demarco, T., Risk Management for Software Projects, The Atlantic System Guild, Camdem, ME, 2004.

[13] Ejiogu, L. O., " Five Principles for the Formal Validation of Models of Software Metrics “, ACM SIGPLAN Notices, Vol. 28,No. 8, August 1993. 
International Journal of Software Engineering \& Applications (IJSEA), Vol.3, No.1, January 2012

[14] Fenton, N.E., and Pfleeger, S.L., Software Metrics - A Rigorous \& Practical Approach, 2nd Edition, International Thomson Publishing, Boston, MA, 1996.

[15] Fenton, N. E. \& Whitty, R. and Yoshinori, I. Software Quality Assurance and Measurement, A Worldwide Perspective. London: International Thomson Computer Press, 1995.

[16] George, D. and Mallery, P., SPSS for windows step by step A Simple Guide and Reference, Fourth Edition, 2003.

[17] Hammer T. F., Huffman L. L., and Rosenberg L. H, "Doing requirements right the first time", in CROSSTALK, The Journal of Defence Software Engineering, December, pp. 20-25, 1998.

[18] Han, W. and Huang, S., An Empirical Analysis of Risks Components and Performance on Software Projects, in the journal of Systems and Software, vol. 80, 2007, pp. 42-50.

[19] Jacquet, J. P. and Abran, A., "Metric Validation A structured Analysis", $8^{\text {th }} \quad$ International

Proposals, Sept. 17-18, 1998.

[20] Janakiram. D and Rajasree. M. S, "ReQuEst: Requirements-driven Quality Estimator", in $A C M$ SIGSOFT Software engineering notes, vol. 30, no.1, 2005.

[21] Jiang, J. and Klein, G., Software Development risks to project effectiveness, in the Journal of Systems and Software, vol. 52, pp. 3-10, 2000.

[22] Kajko, M.and Nyfjord, J., State of Software Risk Management Practice, in International Journal of Computer Science, vol. 35, no.4, 2008.

[23] Kitchenham, B., Pfleeger, S.L., and Fenton, N., Towards a Framework for Software Measurement Validation, in IEEE Transactions on Software Engineering, 21(12), December 1995.

[24] Kitchenham, B. and Jeffery, D., Misleading Metrics and Unsound Analyses, in IEEE Software, April 2007. nstability on Software Defects, in ACM Software engineering notes, 2004, vol. 29, no. 4.

[25] Kumar, R. Managing risks in IT projects: an options perspective, in Information and Management, vol. 40, 2002, pp. 63-74.

[26] Lee, Y, and Chen, J. Experience in introducing CMM to a telecommunication research organization, Journal of Software Engineering Studies, vol.1, No. 1, 8-16, September 2006.

[27] Loconsole, A., "Measuring the Requirements Management Key Process Area", Proceedings of ESCOM - European Software Control and Metrics Conference, London, UK, April, 2001.

[28] Mahinc, V. and Zabkar, N. Measurement repository for Scrum-based software development process. Conference on computer Engineering and Application (CEA,08) Acapulco, Mexico, January 25-27, 2008.

[29] Park, R. E., Goethert, W. B. and Florac, W. A., Goal-Driven Software Measurement-A Guidebook, Software Engineering Institute Handbook, CMU/SEI-96- HB-002, August, 1996.

[30] Paulk, M. C., Weber, C. V., Garcia, S., Chrissis, M. B., and Bush, M., Key Practices of the Capability Maturity Model Version 1.1, Software Engineering Institute Technical Report, CMU/SEI-93- TR-25 ESC-TR-93-178, Pittsburgh, PA, USA, February, 1993.

[31] Pressman, R. S., Software engineering: A practitioner's Approach, Sixth edition, 2005. 
International Journal of Software Engineering \& Applications (IJSEA), Vol.3, No.1, January 2012

[32] SEI (software Engineering Institute), CMMI (Capatility Maturity Model-Integrated) for development, V,1.2, Carnegie Mellon University, August 2006.

[33] Sommerville, I., Software engineering, Addison - Wesley, eighth Edition, 2007.

[34] Villalon, J., Agustin, G., Hurtado, G., and Gilabert, T., State of the Art for Risk Management in software Acqnisition, SIGSOFT Software Engineering notes, July 2009, Vol.34, No.4.

[35] Wallace, L. and and Keil, M., Software Project Risks and Their Effect on Outcomes, in the journal of Communications of the ACM, vol. 47, No. 4, pp.68-73, 2004

[36] Young, H., Fang, T., and Hu, C. A successful practice of applying software tools to CMM1 process improvement, Journal of Software Engineering Studies, vol. 1, No. 2, 78-95, December 2006.

\section{Appendix A}

\section{Questionnaire and Analysis}

This questionnaire is related to the Risk Management process. Risk Management demonstrates that products fulfill its intended use when placed in its intended environment.

The Risk Management process has seven goals:

1-Determine Risk Sources and Categories

2-Define Risk Parameters

3-Establish a Risk Management Strategy

4-Identify Risks

5-Evaluate, Categorize, and Prioritize Risks

6-Develop Risk Mitigation Plans

7-Implement Risk Mitigation Plans

We would like to measure the achievement of the defined goals, so, we define some statements related to each goal. We suppose that the information in these statements (measures) help us in achievement of the above seven goals. Please, fill the enclosed form by writing $\sqrt{ }$ in the suitable place. Responding to this question: do you think that the statements have an effect on the achievement of the defined goals?

1. Goal1: Determine Risk Sources and Categories

(do you think that these statements (measures) have an effect on the achievement of goal1:

Determine Risk Sources and Categories?)

\begin{tabular}{|l|l|l|l|l|l|l|}
\hline $\begin{array}{l}\text { statemen } \\
\text { serial }\end{array}$ & statements & $\begin{array}{l}\text { Strongl } \\
\text { agree } \\
1\end{array}$ & $\begin{array}{l}\text { Identifying risk } \\
\text { resources that } \\
\text { affect the ability of } \\
\text { the project to meet } \\
\text { its objectives. }\end{array}$ & $\begin{array}{l}\text { Neither agree } \\
\text { nor disagree }\end{array}$ & disagree & $\begin{array}{l}\text { Strongly } \\
\text { disagree }\end{array}$ \\
\hline 2 & $\begin{array}{l}\text { Identifying } \\
\text { internal risk } \\
\text { resources. }\end{array}$ & & & & & \\
\hline 3 & $\begin{array}{l}\text { Identifying } \\
\text { external risk } \\
\text { resources. }\end{array}$ & & & & & \\
\hline
\end{tabular}


International Journal of Software Engineering \& Applications (IJSEA), Vol.3, No.1, January 2012

\section{Authors}

Mahmoud khraiwesh is an assistant professor at Faculty of Science and Information Technology in Zarqa University. He received his MSc degree in computer science from Jordan University, Jordan, in 2002 and his $\mathrm{PhD}$ degree in computer information system from The Arab Academy for Banking and Financial sciences, Jordan, in 2006. His area of research is in software development measures.

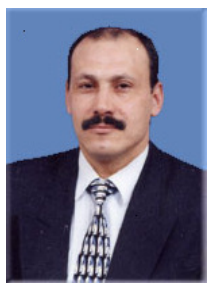

